\title{
THE PERSISTENCE OF COMPLEMENT FIXING PHASE 2 ANTIBODIES AFTER ACUTE COXIELLA BURNETI INFECTION
}

\author{
LIEUTENANT COLONEL A J SPICER, MD, MRCP, DCH, DTM\&H, RAMC \\ Queen Elizabeth Military Hospital, 'Woolwich
}

SUMMARY: An investigation was undertaken in Cyprus to ascertain the persistence of Phase 2 complement fixing antibodies to Coxiella burneti.

Two conclusions resulted. Firstly, that phase 2 complement fixing antibodies are not detectable for longer than twelve to sixteen months after most minor Coxiella burneti infections, and secondly that minor infection occurs much more commonly than overt $\mathbf{Q}$ fever.

The association of these two findings allows a time dimension to be added to antibody prevalence surveys by showing that they largely reflect the occurrence of Coxiella burneti infection in the recent past.

\section{Introduction}

The complement fixation test using phase 2 antigen is often employed in population surveys to determine the prevalence of Coxiella burneti infection, but little is known of the time span which such surveys represent as there is a paucity of knowledge regarding the persistence of phase 2 antibodies.

Babudieri et al (1952) and Siegert et al (1953) found no appreciable amounts of antibody 12 months after mild attacks of $Q$ fever, whilst with more severe attacks antibodies usually persisted for more than one year, and sometimes up to five years (Babudieri 1954). Caughey and Dudgeon (1947) in a retrospective investigation into the cause of an epidemic of a typical pneumonia found complement fixing antibodies to Coxiella burneti in titres up to $1: 64$ in 19 out of 20 cases, almost two years after infection. Powell and Stallman (1962) found titres up to $1: 64$ in 71 per cent of 51 cases after two to three years. Neither Caughey and Dudgeon, nor Powell and Stallman, were studying the persistence of phase 2 antibodies and their results have not been remarked upon before in this context.

Seventy-eight British soldiers stationed in the Eastern Sovereign Base Area of Cyprus contracted Q fever between December 1974 and June 1975. No obvious cases occurred among the civilian population, which was swollen by 40,000 refugees from the Turkish invasion, living under conditions of human and animal overcrowding. The source of infection was an abortion epidemic caused by Coxiella burneti among 21 mixed flocks of sheep and goats grazing in and around the Sovereign Base Area. A serological survey three months after the end of the $Q$ fever epidemic revealed that 59 per cent of local villages, and 84 per cent of shepherds, all without a history of infection, hả complement fixing antibodies of $\mathbf{Q}$ fever. Whilst the circumstances suggested a subclinical epidemic in a largely immune population, it was not possible to make a more certain deduction as little was known of the persistence of phase 2 antibodies. The details of the epidemic have been previously reported (Spicer et al 1977).

The present investigation was undertaken to determine the persistence of phase 2 antibodies, to enable more information to be obtained from population surveys. 
The Persistence of Complement Fixing Phase 2

Antibodies after Acute Coxiella Burneti Infection

Patients and methods

Twenty-one soldiers had repeat serology performed 12 to 16 months after suffering $Q$ fever, using the complement fixation test and phase 2 antigen. They were divided into three groups according to the severity of the illness :-

(a) X-ray changes of pneumonia for less than 14 days. Symptoms for less than seven days.

(b) X-ray changes for 14 to 28 days. Symptoms for seven to 14 days.

(c) X-ray changes lasting more than 28 days. Symptoms for more than 14 days.

Eleven asymptomatically infected Cypriots, and 13 asymptomatically infected shepherds from 10 flocks harbouring Coxiella burneti, had serology repeated 13 to 16 months later.

Serology was also performed on 106 consecutive adult Cypriot villagers, with no history of $\mathbf{Q}$ fever, who entered the British Military Hospital compound during a two day period. They comprised a mixed group of patients, visitors and hospital staff. This was a similar sample to a survey of 100 Cypriots from the same region 12 months earlier, when 59 per cent were found to have phase 2 complement fixing antibodies with titres ranging from $1: 10$ to $1: 320$.

The complement fixation test was performed at the Royal Army Medical College, London, by a technique adapted from that of Bradstreet and Taylor (1962). Phase 2 antigen was kindly supplied by Dr C M P Bradstreet of the Standards Laboratory for Serological Reagents, Colindale, London.

\section{Results}

Out of the 11 asymptomically infected Cypriots five had no demonstrable bodies, whilst only one out of 12 in groups (b) and (c) was seronegative. Titres ranged from $1: 20$ to $1: 80$ in group (a) and $1: 40$ to $>1: 1,280$ ) in groups (b) and (c). With one exception all showed a decline in titre, which was of two or more dilutions in 14 of the 21 soldiers (Fig. 1).

Out of the 11 asymptomically infected Cypriots five had no demonstrable antibodies 13 to 16 months later, and seven showed a decline in titre of two or more dilutions (Fig. 2).

Only two of the 13 shepherds were without antibodies after 14 to 15 months. One of them had lost his flock as a result of the Turkish invasion. Eight showed no change in antibody level and 11 were still within one dilution of the first titre (Fig. 3).

Fourteen (13 per cent) of the 106 Cypriot Villagers had antibodies, with titres of $1: 10$ or $1: 20$. The percentage distribution of this and the earlier population sample is shown in Table I.

\section{Discussion}

The results reveal a direct relationship between severity of infection and persistence of circulating antibodies. Whilst more than half of the cases with minor or asymptomatic infection were seronegative by 16 months, all except one case in the two more severely affected groups still had antibodies. The pattern of these results accords with the findings of Babudieri et al (1952) and Siegert et al (1953), but there is a quantitative difference in that all of their milder cases were without antibodies after 12 months. 


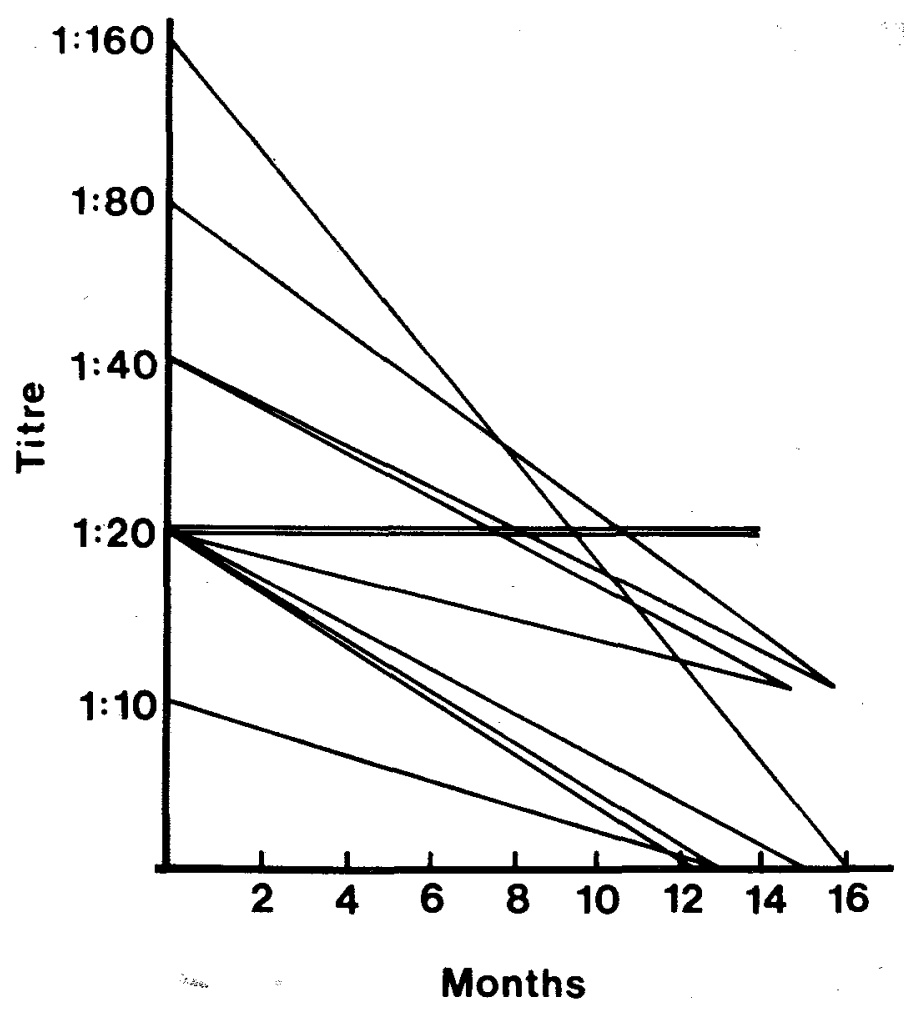

Fig. 1. Paired complement fixing phase 2 Coxiella burneti antibody titres of 21 $B$ ritish soldiers with $Q$ fever.

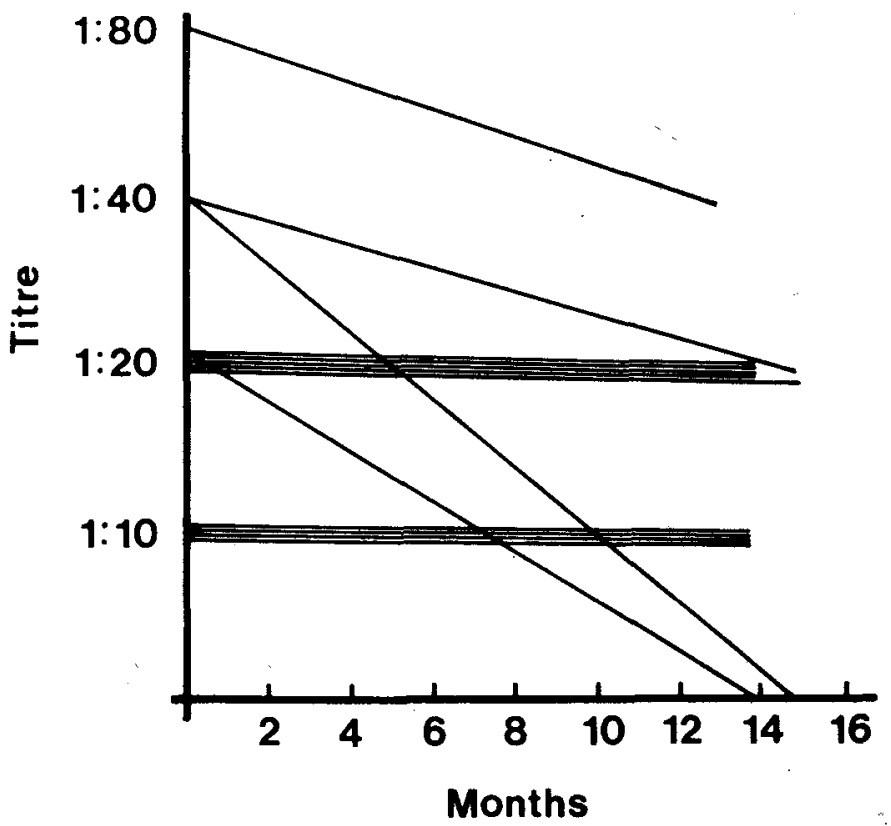

Fig. 2. Paired complement fixing phase 2 Coxiella burneti antibody titres of 11 asymptomatically infected Cypriot villagers 


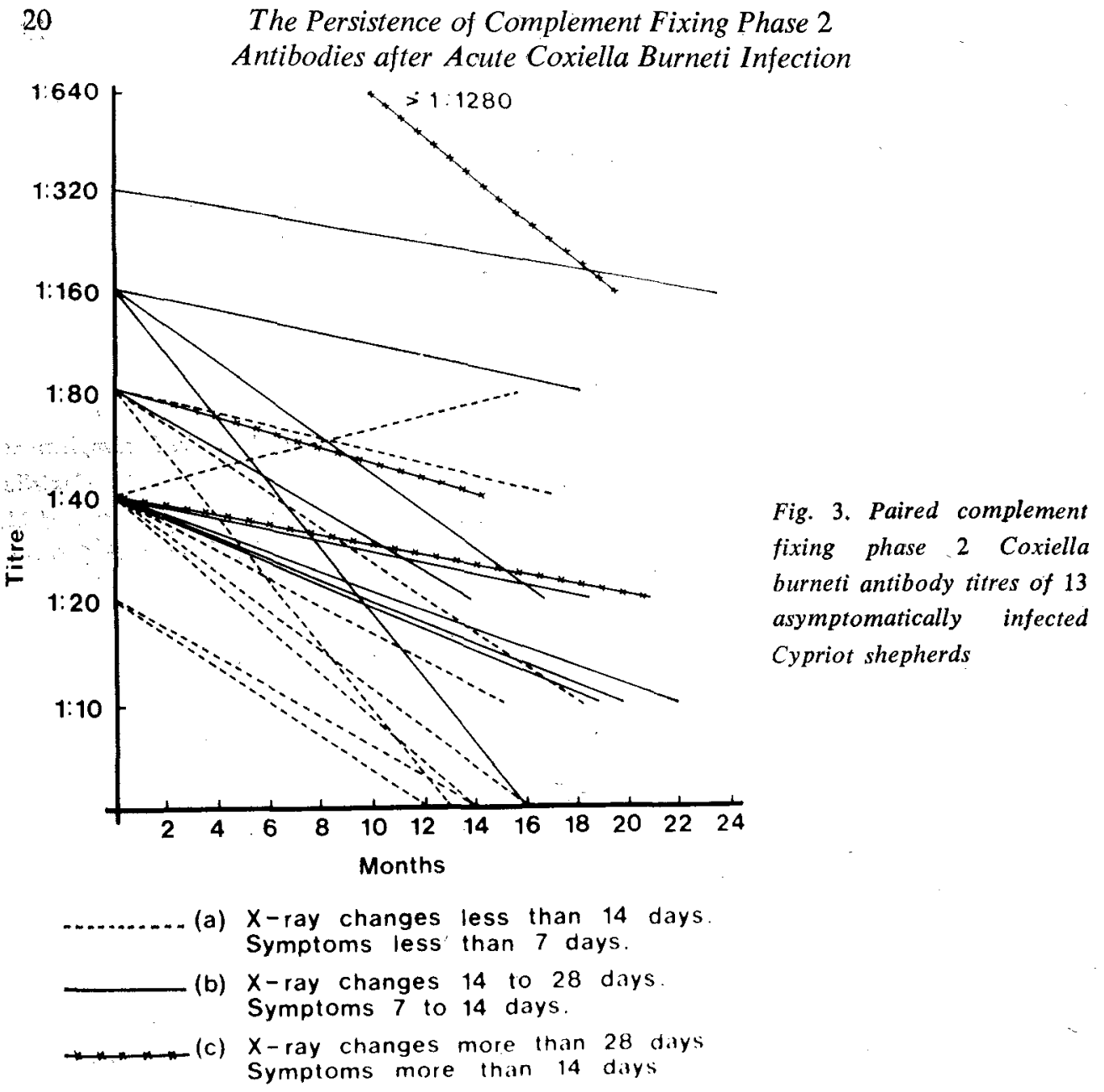

Table I

Percentage distribution of complement fixing phase 2 Coxiella burneti antibody titres of 100 Cypriot villagers in 1975 and 106 Cypriot villagers in 1976

\begin{tabular}{|c|c|c|c|c|c|c|c|}
\hline Titre & Negative & $1: 10$ & $1: 20$ & $1: 40$ & $1: 80$ & $1: 160$ & $1: 1320$ \\
\hline $\begin{array}{c}\text { Cypriot villagers } \\
1975\end{array}$ & 41 & 9 & 41 & 4 & 3 & 1 & 1 \\
\hline $\begin{array}{c}\text { Cypriot villagers } \\
\text { 1976 }\end{array}$ & 87 & 10 & 3 & & & & \\
\hline
\end{tabular}

There: wàs a general concordance between severity of infection and height of titre, and it seems likely that the lesser antibody response associated with minor infection accounts for the shorter persistence of antibodies in this situation.

Indirect evidence of antibody persistence is provided by the two population surveys. The high prevalence of 59 per cent shortly after the end of the $Q$ fever and abortion epidemics, falling to 13 per cent in a similar sample 12 months later. demonstrated in a different way the shorter antibody persistence following minor infection. The fall in prevalence was also accompanied by an overall decline in titre. 
A further important point to emerge from these surveys is that inapparent infection occurs much more commonly than overt $\mathrm{Q}$ fever. This situation is most likely to arise in a population where Q fever is endemic, and Kelly (1974) in a survey from 1968 to 1969 found that 5.3 per cent of the adult Cypriot population had antibodies under normal peacetime conditions.

The findings in the group of shepherds revealed a different pattern. Whilst none could recall symptoms of $\mathrm{Q}$ fever the great majority still had antibodies after 16 months, and mostly at the same titre. This was probably the result of repeated antigen stimulus, and it is relevant that one of the two shepherds who became seronegative also lost his infected flock. A possible explanation of the surprisingly low titres is that a highly primed immune mechanism may destroy rickettsiae before a further antibody response can be evoked. No reports of similar groups could be found for comparison.

Unfortunately it was not possible to extend the study beyond 16 months, as by this time almost all of the original $Q$ fever patients had left the island. Frum the results of Caughey and Dudgeon (1947) and Powell and Stallman (1962) antibodies persisted for more than two years in the majority of moderate to severe cases. Babudieri (1954) recorded a few cases with antibodies persisting up to five years, but he considered this to be a rare occurrence. A patient recently under my care produced a phase 2 antibody titre of $1: 2,048$ whilst suffering from $Q$ fever endocarditis. Ten years later the titre was $1: 192$ and at 14 years it was $1: 40$. This long term persistence probably reflects maximal antibody stimulus. Theoretically, at least, a similar longevity of immune response could follow severe acute infection.

It is concluded that in the majority of asymptomatic and minor cases of $\mathrm{Q}$ fever phase 2 antibodies do not persist for longer than 12 to 16 months, whilst with more severe infections antibodies persist beyond this time. As asymptomatic and minor infection is much commoner than overt disease, population surveys for complement fixing phase 2 antibodies largely reflect the occurrence of Coxiella burneti infection in the preceding year to 16 months.

\section{REFERENCES}

Babudieri, B., Berni, A and Manzi, F (1952). Un episodia di febbre Q a Maccarese. Rendiconti Istituto superiore di sanita 15, 358

BabudiERI, B (1954). Reazione di deviazione del complemento e reazioni di agglutinazione nell infezione da Coxiella burneti. Rendiconti Istituto superiore di sanita 17, 982

BradstreEt, C M P and TAYLOR, C E D (1962). Technique of complement fixation test applicable to the diagnosis of virus disease. Monthly Bulletin of the Ministry of Health and the Public Health Laboratory Service 21, 96

CaugheY, J E and Dudgeon, J A (1947). Q fever: a serological investigation of a group of cases previously reported as primary atypical pneumonia. British Medical Journal ii, 684

Crowther, R W and SPICER, A J (1976). Abortion in sheep and goats in Cyprus caused by Coxiella burneti. Veterinary Record 99,29

Kelly, H B (1974). Q fever in Cyprus: report of cases and a survey of United Nations personnel. International Journal of Epidemiology 3, 47

Powell, $O$ and Stallman, $N$ D (1962). The incidence and significance of phase 1 complement fixing antibody in Q fever. Journal of Hygiene 60, 359

Siegert, R., Simrock, W and Schweinsberg, H (1953). Q-Fieber-Studien. 2 Mitteilung. Zeittiche Entwicklungen and Verweildauer Komplementbindender und agglutinierender Antikoerper bei unbehandelten und behandelten Q-Fieber-patienten. Zentralblatt fur Bakteriologie, Parasitenkunde, Infektionskrankheiten und Hygiene, Abteilung 1, 159

Spicer, A J, Crowther, R W, Vella, E E, Bengtsson, E, Miles, R and Pitzolis, G (1977). $\mathrm{Q}$ fever and animal abortion in Cyprus. Transactions of the Royal Society of Tropical Medicine and Hygiene. 71, 16 